\title{
Quranic Sciences from Abdul Hamid Farahi's Perspective (1863-1930)
}

Jannat Taftahi ${ }^{1 *}$, Seyyed Mahmoud Mirzaee al-Husayni ${ }^{2}$, Ali Nazari ${ }^{2}$

${ }^{1}$ Department of Arabic Language and Literature, Lorestan University, Iran

${ }^{2}$ Department of of Arabic Literature, Lorestan University, Iran

Corresponding Author: Jannat Taftahi, E-mail: jtafte@yahoo.com

\section{ARTICLE INFO}

\section{Article history}

Received: May 12, 2017

Accepted: July 07, 2017

Published: December 01, 2017

Volume: 6 Issue: 7

Special Issue on Language \& Literature Advance access: September 2017

Conflicts of interest: None

Funding: None

\begin{abstract}
Discussions regarding Quranic sciences and gaining cognizance of different issues of this field date back to the advent of Islam. Throughout history, this field has witnessed a surge of valuable research that has been and is being conducted on its various issues. Farahi (1863-1930), the Indian interpreter, due to preventing the introduction of eisegesis and Isra'iliyyat which lack well-accepted sources into the field of Quran interpretation, is known as the interpreter of Quran. In the introduction of Nazm-ul-Quran and his other works, Farahi proposes novel ideas regarding Qur'anic sciences such as coherence, interconnection between verses and Surahhs (or Surahs) of Quran, asbab al-nuzul (occasions of revelation), and the muqatta'at (disjoined letters), etc. He has also put forward some views concerning naskh (abrogation) which are in line with other interpreters' views. Determined and deliberate attempts of this anonymous author in the field of Qur'anic science led the researchers, drawing on library research and descriptive-analytic methods, to shed some light on the views of this noteworthy interpreter and, as a corollary, revive his character.
\end{abstract}

Key words: Interpretation of Nazm-ul-Quran, Qur'anic Sciences, Naskh, Asbab Al-nuzul, Interconnection between Verses and Surahs

\section{INTRODUCTION}

Quran researchers in the field of Quran written a lot about Qur'anic sciences and even some commentators have focused on the discussion of the issues in the introduction of their commentary or in their interpretation texts. Abdul Hamid Farahi is among the commentators (1349 AH) who was born in "Fariha", a village of the city of "Azamgar" in India. He studied Hebrew, rational and traditional sciences, customs of nations, history, and New Western philosophy taught by his cousin "Allameh Shebeli11" and other great teachers as "Molana Abulhasanat Abdulhay Farangi Mahali" and "Molana Feiz Alhassan"" and "Fazlallah Ibn Nematalla Ansari" to serve Quran. He, given the time consequences and in order to avoid the penetration of Isra'iliyyat which lack well-accepted sources into the field of Quran interpretation authored "Nazm-ul-Quran Va Tavil ul- Forqan bel-furghan" to defend the holy manuscript.

Farahi authored over fifty books on Quranic sciences, poetry, grammar and rhetoric in Urdu, Arabic, English and Persian; therefore, he gained the Qur'an knowledge and the stance that few scholars can reach; hence, his contemporaries called him "TarjomanalQuran" (See, Farahi, Publisher Introduction, 2002: 27).

Researchers less paid attention to "Nazm-ul-Quran Va Tavil ul- Forqan bel-furghan" interpretation that is a con- temporary interpretation of Quran. The book in two volumes includes fifteen Surahs of the Quran interpretation in new styles. Abdul Hamid Farahi, in the introduction to this interpretation, briefly addressed the Qur'anic sciences topics to prevent the spread of topics in interpreting the Quran. But detailed views of Farahi, in this regard are authored of their influential five books known as an introductory to "Nazmul-Quran" including: "Alqaed ela oyon al aqaed", "Ahkam al-usol beahkam al-rasol ", "Altakmil fi usol al tavil", "Alrosokh fi marefate alnasekh va almansokh", and "Hojaj al Quran".

The authors of this paper seek to answer the following question:

1. What are Farahi views on the question of cohesion of Surahs and verses of the Quran, manuscripts, disconnected letters, revelation and the definitively of Quran as a source of reference?

As far as researchers know there is no research conducted in relation to this subject. There is some researches on the study of Abdul Hamid Farahi biography and the method of his commentary in Damascus entitled as "Imam Abdul Hamid Farahi va manhajaho fi tafsir" in 2004 with few examples of their interpretation of Quranic Surahs in brief. There is also another study entitled "Imam Abdul Hamid Farahi va johodoho fi tafsir va olom al Quran" authored by Mohammad Fraid Ravi IBN Abdulla Malezi in 2015, introducing 
Abdul Hamid Farahi books, and interpretation method and comparing them with other interpretations, without any reference to his views on Qur'anic sciences. However, the current paper addresses some of his Qur'anic sciences theories, including cohesion of cohesion of Surahs and verses of the Quran, manuscripts, disconnected letters, revelation and the definitively of Quran as a source of reference.

\section{COHESION OF SURAHS AND VERSES OF THE QURAN}

Studying all Surahs of the Quran shows consistency and the absence of any discrepancy and disagreement that is the quality of cohesion of Surahs and verses of the Quran. Believing in the cohesion of Surahs and verses of the Quran, while interpreting, leads the interpreter to the alignment of all the verses and internal cohesion and not to interpret verse independently. In this light, the interpreter considers the Quran systematic and interrelated with deep connections between each section and other parts of verses. Of course, the commentator cannot benefit from the overall coherence of the verses in interpretation if does not believe in the verses proportionality and their descending or in whole revelation of the whole or in part of verse (Moadab, 2009: 142). On this topic, having checked the "order" and "proportionality" of the word and the term, we will review them from the perspective of Abdul Hamid Farahi.

\section{THE LITERAL MEANING OF THE TERM "NAZM"}

The term "Nazm" literally mean arrange, order and sort things (See, Amid, 2010 p: 1128 and Bandar Rigi, 1993: 592). And pearl beads etc. that regularly drawn on yarn and are arranged side by side are called "monazam"; (See, Ibn Manzur, 1414 AH: vol. 12, 578-579). And the yarn or string that binds them together and threads beads and bangle is called "nezam" with the plural form of "Nozom" (See, Bandar Rigi, 1993: 592; and Firozabadi, 2005: 1162). "However, what is meant by "nazm" by the Quran scholars is the interconnection between some verses of the Quran to act as a unit of meaning, coherent and integrated" (Zarkeshi, 1984: vol. 1, 36) Every Surah of the Qur'an, although with different subject, is a united whole with its beginning interconnected to its ends and vice versa seeking the same goal. One who pursues Quranic "nazm" should take into account all components of a verse, in addition to the verse"nezam" (Deraz, 1957: 159). None of predecessors could explain and consolidate this theory as Farahi did, and write about. In fact, Farahi is the one, who brought science to its proper place based on a solid foundation. He clarified the science method, definitions and practices and authored a book entitled "Dalayel al nezam" (Farahi, 2000: Publisher Introduction, 5-6).

Mustansir Mir, in the introduction to the book "Ensejam dar Quran"writes about coherence in Quran: Muslims interpretation of Quran is of different types: traditional, theological, literary, and philosophical and legal. However, the common interpretation issue undoubtedly is the verse to verse detailed attitude approach to the Quran. Major interpretation has investigated one or more verses of the Quran without regard to prior of followed verses. Mir writes, this approach led to believe that the verses of the Quran "nazm" and "nezam" is not important in interpretation. Accordingly, there is no surprise that many western authors concluded that the Quran is not coherent. Then, Mir in reference to Amin Ahsan Eslahi, the Pakistani commentator interpretation, adds that he knows Quran of such a coherence unique in itself that complements the Quran meanings. The term used by Eslahi (1418 AH) following his teacher (Abdul Hamid Farahi) to show the Quran coherence is "enzebat, tartib va nezam" (Mustansir Mir, 2011: 51-59).

\section{THE LITERAL MEANING OF THE TERM "TANASOB"}

The terms "tanasob" or "monasebat", means to connect two things, proximity and closeness. When we say something "monaseb" with another this means that they are close. The term "nasib" is derived from the same root that means kin, for example brother or cousin and etc (See, Encyclopedia of the Quran, vol. 8, 652 and Zarkeshi, 1984: c 1.61).

"tanasob" literally means the link between two things at any direction. "tanasobat" is either objective or subjective in writings, but in the Quranic science, the term gain more narrow meaning referring to the link between the parts of a verse or some verses as well as the link among Surahs. The science of "monasbat" is the science to detect the links among various parts of the Quran seemingly discrete and unrelated. Relations either appear among two parts of the same verse or adjacent verses, or etc (Encyclopedia of the Quran, vol. 8, 652).

\section{VERSES AND SURAHS "NAZM" AND "TANASOB" ON FARAHI VIEW}

Abdul Hamid Farahi is among those interpreters believing in the gradual revelation of the Quran; "Those who reject Faith say:" Why is not the Quran revealed to him all at once? Thus is it revealed, that We may strengthen thy heart thereby, and We have rehearsed it to thee in slow, well-arranged stages, gradually" (Forqan, 32) to fix the meaning and then it was compiled, clarified and explained; "It is for Us to collect it and to recite it" (Qiyamat: 17). Contemplation in the Quran verses reveals that the Prophet sorted "nazm" the verses and Gabriel it to the Prophet then, that is the unity of the manuscript and the order to follow it. He in the book "Nezam ul Quran" seeks to detect the order "nazm" in verses (Farahi, 2008: 75). He does not follow philosophers, logicians and Sufis methods on the detection of the Quran "nazm", but relies merely on the holy Quran and writes: There is consensus among past and contemporary commentators that interpret the Quran verse interpret each other, that is the safest and best interpretive method because this method of interpretation makes man familiar with the "nazm" and "tanasob" on verses in the Qur'an,and provides more evidence for thematic relationship with other issues and acts as an incentive to detect the full connections between the verses and to find better and brighter examples in the Quran; and 
gradually leads man to what that is more and more important (See, Farahi, Publisher Introduction, 2000: 5-6).

The holy Quran provides one meaning in various forms in orderly sentences so that the altered statements and terms carry the same concepts. This is like a commander who arranges his troop in different orders and only those who are familiar with the techniques are able to discern the facts. The Quran "nazm" is such that only those familiar with the Arabic literature and deep understanding of the Quranic concept can understand it (Farahi, 2008: 41). The differences in style in the Qur'an are because of the beauty of the word and avoid duplication; because if a concept is repeated in different methods several times, if did not understand its meaning, certainly somewhere the concept will be understood. Holy Quran says: "See how We explain the signs in diverse ways; that they may understand" (Anaam, 65) (ibid: 40-41). However, this "nazm" in the Holy Quran is done in several ways: 1) the subject may be the main theme of a Surah;2) it should be used as proof and argument; 3 ) may be expressed concisely; 4) may be expressed in details; 5) prior expressed; 6) later expressed; 7) be expressed as a single issue; 8) and come together with other issues (ibid., 42).

The meaning of "nazm" in "Nazm-ul-Quran Va Tavil ul- Forqan bel-furghan" is the unity of subject referred to by the contemporary authors. Farahi writes: "Sometimes "tanasob" is among non-adjacent not interconnected verses, so that the next verse, by far, is connected to the former verse, this lack of connection between adjacent verses is frequent in the Quran and sometimes we see that verse or group of verses with the theme connection are far apart. In these cases, if the "nezam" is specified in the Qur'an, the meaning of words linked together and integrated word there will show an image and one will have a clear picture and if viewed from this perspective the beauty, coherence and clarity of the word will prevail (ibid: 75). Thus, the concept of a Surah "nezam" means the unity of word and "tanasob" with the former and later Surah. As parenthetical verses may be, Surah do the same, according to the theory of "nazm", the Qur'an from beginning to end, is a united theology and discipline fits in all sections. Therefore, "nezam" provides Surah with unity and independence so that Surah becomes completely independent with its components built upon. To create a better "nezam" the word should be in a good "nazm", "tanasob" and be integrated (See; Farahi, 2009: 75).

Farahi, by the "Quranic nazm" concept means to provide a simple interpretation of Quran that agrees that of the Prophet time, perceiving the meanings from the depth of the Surah "nezam" and consolidate the Quranic perceptions logically and reasonably (Farahi, 2008: 15). Farahi, for example to show the "nazm" of the verses of Surah al-Hamd writes: "Praise be to Allah, the Cherisher and Sustainer of the worlds"(al-Hamd: 2) that shows the state of gratitude, and "Most Gracious, Most Merciful"(al-Hamd: 3) forms optimism and knowledge of God in human and the appropriate "nazm" here, is that first of knowledge is the understanding of the blessings and the first obligations is the sense of gratitude for the blessings that here comes the knowledge of the Merciful and the Compassionate God. Repeated the term of mercy, implies God mercy on thankful people, and then, warns the day of the judgment encouraging praying, crying and begging and finally, trusting in God; and, how beautiful is the trust following the optimism (Farahi, 2009: 106).

Some commentators and scholars of the Qur'an know Quranic Surahs' interconnected and argue that the last verse of each Surah is linked with the first verse the next one (Babaei, 2000 p: 142-143).

Farahi believes that not only the verse of the same Surah are linked together and integrated, but this association and consistency is present among Surahs', as well. Farahi, interpreting each Surah, first provides its relationship with the former and the later Surah in the beginning, and then reviews and interprets the verses relations to others. For example:

1. Farahi, writes on the relationship and "nazm" among the verses of Surahs: "Both Surahs "Nasr" and "Lahab" are based on the verse "And say:" Truth has) now (arrived, and Falsehood perished: for Falsehood is) by its nature (bound to perish" (Isra: 18); where the Surah "Nasr" is based on the first part, namely "Truth has) now (arrived)" and the Surah "Lahab" is based on the second part, namely "and Falsehood perished". Farahi, writes seemingly, "Lahab" emphasizes on the meaning of the followed "Lahab" and provides the good news that "God helped His Messenger and His were enemies killed" (Farahi, 2008: 575-576).

2. Commentator writes about "nazm" and the Surahs' connection; for example, Al-Baqara and Fatiha connection and cohesion: Surah Al-Baqarah is the Quran forehead. Al-Baqara is the crown of the Quran and Fatiha is the jewel. Al-Baqarah is the interpretation of the Fatiha with all the brevity and consistency of expression and is as an introduction to the Holy Qur'an to describe its content; for detailed after brevity is the best ways to teach that is in the Quran. As Allah says: "Alif. Lam. Ra. (This is) a Book, with verses basic or fundamental (of established meaning), further explained in detail, - - from One Who is Wise and Well-acquainted) with all things".

Farahi, after explaining the contents of Al-Baqarah Surah, in relation to cohesion with next Surah, Ale-Emran writes: Ale-Emran follows Al-Baqarah because of their similarities. There is a narration that "Whoever reads Al-Baqarah and Ale-Emran, on the Day of Judgment both Surah cover him as if a cloud shadow over his head" (Kafami, 1405 AH: 439).

This means these two Surahs are great blessings for believers on the Day of Judgment. Then he gives some reasons for Al-Baqarah preceding Ale-Emran (See, Farahi, 2000: 29-31).

\section{FARAHI REASONS FOR CONCERN TO THE QURANIC NAZM}

Including those caused, Farahi concern to the Quranic Nazm is as follows:

1. Differences in interpretation: according to Farahi, differences in interpretation are due to lack of attention to the relationship between verses. If the Quranic Nazm and the word are clear, everyone will gather under one flag and one word. The verses: "Seest thou not how Al- 
lah sets forth a parable? - - A goodly Word like a goodly tree, whose root is firmly fixed, and its branches) reach (to the heavens" (Ibrahim: 24), and "And hold fast, all together, by the Rope which Allah) stretches out for you (and be not divided among yourselves" (Ale-Emran" 103).

2. Scientist's lack of the ability to defend the Quran: More unbelievers found faults with the Qur'an in term of flaws in nazm, and many Muslim scholars used the verse "It is a grievous thing that issues from their mouths as a saying" (Kahf: 5) rather than witness to the truth and to defend the Book of Allah.

3. The secret meaning of the word: It is no secret that the nazm of the words, is that if left unchecked, part of its meaning is abandoned, and whoever does not understand the Qur'anic nazm is deprived of the understanding of a lot of concepts.

4. Following the nazm of the Qur'an: God has revealed His Book progressively since come to be established, "he unbelievers ask: 'Why was the Koran not sent down to him all at once? "As such We strengthen your heart thereby, and We have recited it very distinctly." (Forghan: 32). And then, meaning of the verses was gathered, recited and clarified: "It's gathering and reciting is upon Us."(Qiyama: 17). Therefore, the Surah, when reached the end was put together by God and explained. Reflection on the Quran verses shows that the Prophet (PBUH) on Gods command put verses in their place (nazm) and Gabriel recited the Surah to the Prophet (PBUH) and it is the same as reading the Qur'an and order to following it.

5. On the nazm of the verses of the Quran: Whoever familiar with the beauty, clarity and nazm of the Quran verses and their proof and place with complex wisdom assures more faithful to the book of God; because most of it lies in the nazm of the Holy Quran (See: ibid. 15-20).

\section{THE QURANIC COMMANDS ABROGATION}

The Quranic commands changes are one of the old discussions in the Quranic science (Seyoti, vol 2: 20; Zarkeshi, 1984: vol 2: 151-176). And the effects of this topic in interpretation and jurisprudence are massive. In this section, Abdul Hamid Farahi view on the manuscript commands changes, changes categories, provisions and principles and wisdom will be repealed.

The Quranic commands abrogation principles: Farahi in his book "Alrosokh fi marefat al nasekh val mansokh", notes to the importance of the abrogation and discussed the issue separately. He knows Islamic scholars dispute on the issue as to quarrel about words. He explains abrogation on four principles:

1. As long as we can make the agreement between general and specific, detailed and concise and warrant and waste, we do not warrant revocation. For example, God forbids marriage to a pagan woman and elsewhere prohibits marrying adulterous women. Here also is the second forbidding includes the first, as well.
2. The manuscript commands abrogation is when there is disagreeing on a verdict and reasoning proves one better than the other, for example "None of Our revelations do We abrogate or cause to be forgotten, but We substitute something better or similar: Knowest thou not that Allah Hath power over all things" (Al-Baqarah: 106).

3. Sentences should gradually be expanded; it will be better and easier if people are guided gradually from easy to difficult. And if the opposite happens, it is because of the wisdom and expediency. As were the reduction on the number of combatants ${ }^{3}$ as well as evening prayers ${ }^{4}$ and Allah revealed the interest it off well to know that we are not opposed to the original sentence; for the first sentence was for those who were stronger and more constant and the second included poor people have been added to them.

4. The change and the changed into are clear in the wordings. Farahi, provides the verse 185 of Al-Baqarah as a changed verse: "God desires ease for you, and desires not hardship for you; and) He desires (that you fulfil the number, and magnify God that He has guided you, and haply you will be thankful." (Al-Baqarah: 186). Here "even as it was prescribed for those that were before you haply you will be godfearing" (Al-Baqarah: 183) commanded on the Ashura day fasting that was incumbent on Jews. Tradition also specifies that the Prophet had agreed on Ashura fasting along with the Jews. That day, in the month of Rabi al-Awwal marks the ninth month of the Jews. The verse shows that the fasting was on a specific day: "that you should fast is better for you if you but know" (Al-Baqarah: 184). Those unable to fast punished by ransom and then according to this verse clarified that fasting is better. But when God distinguish between Jews and Muslims, and ordered the hatred of the Jews and turned Qibla, also changed the fasting period to Ramadan and in the end, the ransom was changed to fasting. All these cases are the turn to the best from the better (See, ibid. 146) that the only abrogation of the judgment in verse recitation of the verse is abrogated.

\section{CLASSIFICATION OF ABROGATION}

(A) Abrogation of preceding rules

Farahi knows more abrogation on the previous verdicts and divides them into two general parts:

(a) Abrogation of previous verdicts that it is better to human progress;

b) The return of the principle of law that has been forgotten

Farahi knows the verse "Those unbelievers of the People of the Book and the idolaters wish not that any good should be sent down upon you from your Lord but God singles out for His mercy whom He will God is of bounty abounding" (Al-Baqarah: 105) of the second type and writes that they are envious and God is of bounty abounding. Also, "None of Our revelations do We abrogate or cause to be forgotten, but We substitute something better or similar: Knowest thou not that Allah Hath power over all things" (Al-Baqarah: 106) of the 
first type and writes it is the example of the abrogation of previous rules. And we will provide with the rules better.

(B) Abrogation of heresies and caprices

Farahi knows the verse "but God annuls what Satan casts, then God confirms His signs surely" (Hajj: 52) the abrogation of slander and lies of the Jews and Christians through Quran. God has abrogated many Jews lies in their rituals, wrong beliefs as belief in the Trinity, believing that Jews are the sons of God, and his friends; the belief that God after creating the heavens and the earth on Saturday was tired and rested; and.... the Quran abolished them all (ibid. 163-164).

\section{ABROGATION OF THE QURAN WITH THE QURAN AND THE TRADITION WITH THE QURAN}

Studying the writings of Farahi on abrogation we see that unlike many Sunni commentators and scholars, he believes in abrogation of the Quran with the Quran and the tradition with the Quran and generally rejects abrogation of the Quran with the tradition (Farahi, 2008: 30). The idea of abrogation of the Quran with the Quran is accepted by some hadith narrators, but many are opposed to it. Shafee and Hanbali are among Sunni scholars agreed with the concept. Shafee says: abrogation does not happen only by the Quran with the Quran, according to the verse "None of Our revelations do We abrogate or cause to be forgotten, but We substitute something better or similar: Knowest thou not that Allah Hath power over all things" (Al-Baqarah: 106) (Abuzahra, 1958: 195-196). Farahi does not value to the word of jurists and theologians who reject this view and believe that the tradition of the Prophet (pbuh) can abrogate the Word of God, and knows their words not more than illusions and errors (Farahi, 2008: 30).

\section{THE MUQATTA ' $\bar{A} T$}

Interpreters, translators, researchers, and Quranic sciences professionals expressed diverse and sometimes disparate perspectives and opinions about The Muqatta'āt. Some are as follows, and then Abdul Hamid Farahi view will be discussed.

\section{THE CONCEPTUAL MEANING OF THE MUQATTA' $\bar{A} T$}

There are a variety of views on The Muqatta āt including:

1. The Muqatta'āt are concepts that no one knows their meanings but God, (See, Tabarsi, 1981 Sun: Vol. 1, 55 and Najafi Khomeini, 1398 AH: Vol. 1, 31).

2. These letters are the Qur'an Mutashabihat that their science is with the Prophet and the Imams (AS) (See; Hosseini Shah Abdulazimi, 1984: vol. 1, 50 and Mirza Khosrowani, 1390 AH: Vol. 1, 44).

3. They are the names of Surahs, and each Surah is known by the letters starting it (See, Tabarsi, 1998 Sun: Vol. 1, 15; Tabarsi, 1981: vol. 1, 55 and Qarati, 2004: vol. 1,41$)$
4. They are the God's Most Great Name (See, Hosseini Hamedani, 1404 AH: Vol. 1, 34; Rezaee Isfahani, 1425 AH: 56-72 and Qarati, 2004, vol 1: 41).

5. They are derived from the attributes of God (See, Tabarsi, 1998 vol 1, 15).

6. Swear oaths that God is with them (See, Tabarsi, 1998, vol. 1, 15 and Qarati, 2004: vol. 1, 41).

7. The Muqatta ât are the mystery of the Qur'an (See; Hosseini Zafarae Isfahani, 2004: 14; Hosseini Hamedani, 1404 AH: Vol. 1, 34 and Qarati, 2004: vol. 1, 41).

8. Hieroglyphic letters: "Quran has borrowed these letters from the hieroglyphic language, once were used to write and speak the international language prior to Islam. It is the same for male and female and singular and plural: the singular male. In addition, The Muqatta ât are known to be the roots of ancient Egyptian words, such as names of cities, tribes, clans, groups, plants, and the mountains" (Adle, 2009: 10, 11 and 20).

\section{THE MUQATTA' $\bar{A} T$ ON FARAHI VIEW}

Abdul Hamid Farahi, knows the Muqatta'àt derived from the letters of the Hebrew that is very close to the Arabic language. He wrote about the first verse of Al-Baqarah: "LM) is an independent sentence, (ALM), as it means in the other names before the start of books, chapters, and topics (See, Farahi, 2000: 68). The names of the Arabic, are not absolute sound like names in Hindi and English, but names for objects and images of them, so many of these letters are names of the objects and remains graven images of objects in those letters; as characters, remnants of that early representations, based on the shapes of the letters. It is clearer when we look at the linear forms of Hebrew letters. For example, the letter "Ta" in Hebrew means the snake and is $v$, and we see the Surah (Taha) is about the story of Moses and his stick change into a snake.

Other Surahs' with The Muqatta 'ât (T) including Qesas, Shoara, Namal witch start with "tasinmim", all start with the story of Moses (pbuh) and his stick change into a snake and besides these four Surahs, only the Surah Aaraf taks the story Moses (PBUH) along with other earlier prophets as Noah, Hud, Salih, Lot and Shoaib (pbuh). Previously, some of the earlier scholars such as Sakhavi called Surah Taha the Surah Kalim, or Hazli called it Surah Moses. Or in Hebrew "alef" was the name for the cow and was in the form of the cow's head and "Ba" means the house, the letter "Jim" with the noun form of "jamil" meant camel, and this is clear for whoever familiar with the Arabic writing and or the letter "Nun", which means fish, and the Surah in the Qur'an is named with this letter is about the prophet "Younus" and did not name the other prophets (See, ibid., 96-98).

\section{REVELATION}

Revelation includes the events at the time of the Prophets (PBUH) and events happened before quoted in the Quran (Marefat, 1415 AH: Vol. 1, 254). For example, we say a certain verse is revealed on infallibility of prophets or angels or Noah or Abraham or Adam and. "(Marefat, dateless: 47). 
The unique way to achieve the revelation of verses referring to the traditions quoted from the companions who witnessed the revelation of the Quran and understand its causes and effort (Vahedi, 1983: 19).

According to Farahi revelation is not the cause for specific verse or Surah but it is the people who caused the verses revelation. Each Surah has a topic or topics with more attention and is the basis of the Surah. Revelation must be found in its own Surah; because the words must be in accordance with the position, as a doctor looking at a patient's prescriptions realizes the illness. Therefore, the words and subject must fit in everything. When it is said that the verses is revealed on such occasion, this means that such matters existed then. It must be understood that all the verses had motivation and reasons and podiums; Thus, Imam Razi problem in the interpretation of the verse in Surah Al-Anaam "And when those who believe in Our Signs come to thee" (Al-Anaam/54) is solved, when he said "I find something wrong here, where people agreed that a Surah was revealed at once, if so, what can be said about any verse of the Surah that the reason for its revelation was such and such". Zarkeshi writes: "Among the companions and followers methods was that whenever one of them said, "This verse has been revealed about this issue," the meant the verse includes the sentence, not that the same problem was the reason for the verse revelation (See, Farahi, 2008: 25 and Siyoti: Vol. 1, 32).

According to Farahi, the purpose is not the case; it means that newly created concept for the Arab, causes and something belonging an associated with it. As stated in Surah al-Kahf: "and We gave him a way to everything and he followed a way" (al-Kahf: 84-85), as well as "so I may reach the cords the cords of the heavens" (Qafer, 36-37), and this concept abounds in Arab language. In his opinion, should be the revelation of the Quran should be sought in the Quran and the confirmed the correct traditions should be used, traditions that do not destroy the Quran Nazm. Whoever is looking for the truth and comforting certainty should clarify the status of nazm, and avoid what diminishes the nazm (See, Farahi, 2008: 27). The point distinguishing Farahi from other commentators is his attention to nazm with no attention to the time of revelation (See, ibid. 26-27).

\section{FARAHI REASONS RELATED TO THE REVELATION}

Farahi enumerates causes for severe need of revelation science in the book "Rassael fi ulom al Quran". He believes in case of faults in revelation people are misled as the following:

a. The void may change meaning and destroy it;

b. The false is a veil that prevents the nazm;

c. The false cause's obstacle to understanding the Quran (See, Farahi, 2011: 128).

\section{FARAHI BELIEVES IN THE GRADUAL REVELATION OF THE QURAN}

Abdul Hamid Farahi asSheikh Mofid as Ayatollah Marefat believes in the gradual revelation of the Quran. He, accord- ing to the verse "he unbelievers ask: "Why was the Koran not sent down to him all at once?' As such We strengthen your heart thereby, and We have recited it very distinctly" (Forghan/32) believes that the Quran was not revealed all at once, but gradually revealed, then some of its provisions are given full complement (See, Farahi, 2008: 68). He writes about it:

God, has revealed Holy Quran according to time conditions as the tree is irrigated gradually and slowly to be fixed firmly rooted in the soil and grow and become larger, a lot of watering destroys its root, and loosens the earth (See; Farahi, 2011: 132).

\section{SUBJECTIVE OR OBJECTIVE NATURE OF THE HOLY QURAN}

When we talk of the implications of a discussion, in fact, we talk about the relationship between word spoken and its content. Implications have three modes: the first is deals with certain implications, this means that the purpose of that statement is certainly known and it is objective; the second is that the implication is at the level of suspicion or surmise or conjecture that is the subjective implication. This means that the intention of the talk is suspected. The third and final mode is where there is no clear implication. This means that we do not know the literal meaning of the words (See, Sadeqi Tehrani, 2014).

\section{SUBJECTIVE OR OBJECTIVE NATURE OF IMPLICATIONS OF THE HOLY QURAN ON FARAHI VIEW}

Since Farahi believes in the revelation of the Qur'an, he also acknowledges the objectivity of the Quran. He knows the start of subjectivity implication of the Quran by the followers that some of the revelations were destroyed, and the Quran was interpreted by companions' effects. In such circumstances, there was some disagreement about aspects of a single meaning and weak traditions have grown and books of interpretations were filled with Jews and Christians false stories and thereafter, philosophy appeared with differences on ideas.

Each sect adhered to favored traditions and philosophies to the extent that the appearance also seemed confused; and ways of interpreting the Quran became dark and the door was closed in the comments and traditions, and the Quran and to understanding its rule was vague and confused. Farahi stated that the medication to this incurable disease is merely resorting to the Qur'an as the Book of God and the return of traditions and ideas to it and to accept the objective nature of the Quran implications. This is to accept that there's only one interpretation and to achieve the following principles:

1. Instead of inquisitive in the Qur'an, should ponder, because people with a moment of reflection on the Quran find answer and surrender;

2. Should not seek the details of story accounts, all humans are curious and their perceptions are based on their personal experience, and recognizing and identifying issues by name or shape or their places and say: "What did God 
desire by this for a similitude" (Al-Baqarah: 26), "what she may be" (Al-Baqarah: 70) and or "what her colour" (Al-Baqarah:69). Interpreters to meet the people needs fabricated stories and details were not from the Quran that caused different meanings;

3. Quran should be the only resort in sensitive situations and hadith and traditions interference with the interpretation should be avoided.

4. definitive rules should be issued in relation to religious laws out of the Quran; because the carelessness in dealing with the opposition in such cases causes the ignorance and misguidance and created multiple meanings for the Qur'an;

5. Should not debate in theological because the causes intrigue unbelief and heterodoxy, and to escape from this predicament the Quran should be considered objective, not subjective (See; Farahi, dateless: 32- 35).

Farahi in "Nazm-ul-Quran" interpretation uses only the meanings proven to be true; for views without reasons in interpretation misleads people. He writes on the objectivity of the Quran implications: Some apparent facts are hidden to us; such as the existence of God and His oneness, the spirit, or the Day of Judgment,

Whoever has the vision, does not doubt in theses affairs, for example, the sun is shining and sugar is white and clear. However, they perceived differently by the blind, and the one eyed and feverish. That is why Allah Almighty says: "a guidance to the godfearing" (Al-Baqarah: 2). (See; Farahi, 2008: 39-40). Thus, to prove the objectivity of the Quran implication clear and similar verses should be separated to prevent disagreements and the emergence of wrong sects.

\section{CONCLUSION}

1. Farahi, by Nazm Surah, means the connection between two adjacent Surahs in terms of the same concepts and Tanasob. He believes, not only the verses of a Surah are interconnected and coherent, but there is the same connection and coherence among a Surah and its preceding and following one.

2. Farahi believes in the gradual revelation of the Quran He believes the Quran was gradually revealed by God to make man understand it more easily and effectively.

3. Farahi, unlike other Sunni commentators and scholars, believes in the Quran rules abrogation by the Qur'an as well as the traditions abrogation by the Qur'an and rejects abrogation in the Qur'anic manuscripts rules by the tradition.

4. The Muqatta 'àt on Farahi views are taken from Hebrew, for example the word Ta' in Hebrew in the form $v$ means snake and the only four Surahs Taha, Namal, Ghesas and Shoara contain The Muqatta 'ât (Ta') the (Telesm) and (Ta Sin) initiating the story of Moses and his stick change into a snake.

5. Farahi believes that the Quran nazm precedes the reasons behind revelations and those reasons are acceptable that do not interfere with the Qur'anic nazm.

\section{END NOTES}

1. Shebeli Namani (1273-1332 AH), for biography see Abdulhay, 1999, vol 8: 1241.

2. Sheikh Fazlo Alhassan Sahar Nafori, for biography see Ravi ibn Abdullah, 2015: 41-42.

3. Al-Baqarah: 249.

4. Mozamel: 20.

\section{REFERENCES}

Abuzahra, Mohammad, "Usol al feqh", Dar alfekr al-arabi, 1958.

Adl, Saad Abdulmotaleb, "Hiroglif in Quran", translated by: Dr. Hamed Sedghi, and Dr. Habiballah Abbassi, Institute of Humanities and Cultural Studies (Human Sciences Comprehensive Portal)., Sokhan Publications, No. 148, 2009.

Ak, Khalid ibn Abdalrahman, "USOL altafsir va alqavaed”, Beiruit, Dar alnafaes, Second edition, 1986.

Amid, Hassan, "Amid Dictionary”, Second edition, Tehran, Farhang Andishmandan, 2010.

Babaei, Ali Akbar, Ghulam Ali Azizi Kia and Mujtaba Rohani, "Methodology of Tafsir", Qom: Institute of Science, 2000.

Bandar Rigi, Mohammad, "Arabic-Persian New Dictionary", Ninth edition, Tehran, Islami Pub, 1993.

Deraz, Mohammad Abdulla,"Nazarat Jadideh fi Quran", Kwait, Daralqalam, 1975.

Feiz Kashani, Mulla Hassan, "Alasfa fi tafsir al-Quran", First edition, researched by: Qaraati.

Farahi, Abdul Hamid, "Altakmil fi usol al atavil", researched by: Mufti Mohammad Saeed, Dateless.

"Rasael fi ulom al quran (second vol)", First edition, researched by: Farahi Ubaidallah and Sheikh Mohammad Amanat allah Eslahi, India: Aldaerat al hamidiya, 2011.

"Nazm-ul-Quran Va Tavil ul- Forqan belfurghan", Baghara Surah, First edition, India: Aldaerat al hamidiya: 2000.

"Dalayel alnezam", researched by: Badr al-Din Eslahi, India: Aldaerat al hamidiya: 2009.

"Nazm-ul-Quran Va Tavil ul- Forqan belfurghan", First edition, India: Aldaerat al hamidiya: 2008.

Farahidi, Khali ibn Ahmad, "Ketab aleyn”, Second edition, Qom, Hejrat Pub, 1410 AH.

Firooz Abadi, Mohammad ibn Yaqob, "Alqamos Almohit", supervised by: Araqsosi, Mohammad Naeem, $8^{\text {th }}$ ed, Alresale Pub, 2005.

Mohsen, "Tafsir Noor", Tehran, Cultural Center of the Quran lessons, $11^{\text {th }}$ edition, 2004.

Hosseini Zafaraee Isfahani, Mirza Baqer, "Familiarity and acquaintance with Quran", Qom, Hram, 2004, Ghaemieh digital publisher of computer Research Center, Isfahan.

Hosseini Shah Abdulazimi, Hossein ibn Ahmad, " Asna ashari tafsir”., first edition, Tehran: Miqat, 1984.

Hosseini Hamedani, Seyyed Mohammad Hossein, “Anwar -e Derakhshan", researched by: 
IBN Atuyeh Anodolosi, Abdul Haq Ibn Qaleb, "Almoharer al vajiz fi tafsir al ketabel aziz", researched by: Abdulsalam Abdul Shafi Mohammad, Beirut, Dar al Kotob al Elmiya, $1422 \mathrm{AH}$.

Ibn Fares, Ahmad, "Mojam maqaees al loqa", researched by: Absulsalam Mohamad Haroon, Dar al fekr, 1979.

Ibn Manzor Mohammad Ibn Mokram, "Lesan al arab”, Third edition, Beiruit, Dar sader, 1414, AH.

Kafami, Ibrahim ibn Ali Ameli, “Almesbah”, Second edition, Qom, Daralrazavi, $1405 \mathrm{AH}$

Center of culture and knowledge of the Quran. Encyclopedia of the Quran, Qom: Boostan-e ketab, 2010, URL: http:// www.maarefquran.com/maarefLibrary/templates/farsi/ dmaarefbooks/Books/8/5.htm.

Keshavarz, Morteza, "Quranic revelation on the views of Mofid and Sadra", philosophical studies, 22, 103-130, 2012.

Khori Shartoni, Saeed, “Aqrab almavared fi fasheal arable shavared", First edition, Qom, Ayatullh Marash Najafi Library, $1403 \mathrm{AH}$.

Khoee, Abulqasem, “Albayan fi tafsir al Quran”, translated by: Mohammad Hassan.

Makarem Shirazi, Naser, "Tafsir nemoneh", First edition, Tehran, Daralketab al-islamiya, 1995.

Moadab, Seyyed Reza and Mosavi Moqadam, Seyyed Ahmad, "The major principles of interpretation of the Quran from the perspective of Shia commentators", Shia Studies, $7^{\text {th }}$ Year, Issue 28, 2009: 117-148.

Mirza Khosrowani, Ali Reza, "Tafsir Khosrawi”, First edition, researched by: Mohammad Baqir Behboodi, Tehran: Islamiyah, $1390 \mathrm{AH}$.

Mohammad Baqer Behbodi, First edition, Tehran, Lotfi Bookstore, $1404 \mathrm{AH}$.

Molazadeh Shakoe, Dateless, Ghaemieh digital publisher of computer Research Center, Isfahan.

Mustansir Mir, Abulfazl Horri, "Ensejam dar Quran”, Study of the effect of corrective discipline in contemplation, religion Magazine Book of the Month, 2011, 163, 51-59.

.............. History of the Qur'an, the eleventh edition, the publisher of printed books. designing the study of Social Sciences, Ghaemieh digital publisher of computer research center in Isfahan, 2008.

.."Altafsir val mofaseron fi sobato alghashib", Second edition, Mashhad, Razavi University of Islamic Sciences, 2004.

.."Altamhid fi olum al Quran", Second edition, Qom, Nashr-e Islami, 1415 AH.

Najafi Khomeini, Mohammad Javad, "Tafsir Asan”, First edition, Tehran: Islamiyah, $1398 \mathrm{AH}$.

Radmanesh, Seyyed Mohammad, “An introduction to Quranic Science”, Sixth edition, 1999, Tehran, Nil Pub.

Razi, Fakhrul-Din, 'Mafatih ul qaeb”, Third edition, Beirut, Dar ehya toras alarbi, $1420 \mathrm{AH}$.

Raqib Isfahani, Hossein ibn Mohammad, "Mofradat Alfaz Quran", researched by: FavanAdnan Davodi, First edition, Beiruit, Dar alulama alshamiya, $1412 \mathrm{AH}$.

Rezaee Isfahani, Mohammad,: a research on scientific miracles of Quran based on the interpretation of "Alserat almostaghim", Hossein Borojerdi, research by: Golam Reza ibn Aliakbar Molana Albrojerdi, Iran, Qom, Almaref alislamiya, $1425 \mathrm{AH}$.

Seyoti, Jallal al-Din, "Aldar almansur fi tafsira al masor", Qom, Ayatullh Marash Najafi Library, 1404 AH.

. "Aletqan fi Ulom al Quran", Cairo, Hejazi, dateless Sadeqi Tehrani, Mohamamad, "Is Quran subjective or objective in reasonings", ghoranian. info/1393/09/13/implication-of-quran, December 4, 2014.

The Holy Quran

Tosi, Mohammad ibn Hossein, "Altebyan fi tafsir al Quran", with an introduction by Sheikh Aqa Bozorg Tehrani, researched by: Ahmad Qasir Ameli, Beruit, Drehya altoras alarabi, dateless

Tabarsi, Fazl ibn Hassan, Agroup of translators, First edition, researched by: Reza Sotodeh, Tehran, Farahani Pub, 1981.

....................translation of "Javame aljame", Motarjeman, Second edition, Mashhad, Islamic Research Foundation of Astan Quds Razavi, 1998.

Tarihi, Fakhr al-Din ibn Mohammad, "Majma al bahrain", Third edition, researched by: Ahmad Hosseini Ashkori, Tehran, Mortazavi, 1996.

Vahedi Neyshaburi, Ali, "Revelation”, First edition, translated by Mohammad Jafar Islami, Islamic Science Foundation, 1983.

Zarkeshi, Mohammad ibn Abdullah, "Alborhan fi ulom al Quran”, research by: Ibrahim, Mohammad Abulfazl, Cairo, Maktaba dar altoras, 1984. 